\title{
Simulation in congenital cardiac surgical education: We have arrived
}

\author{
Harold M. Burkhart, MD
}

From the Division of Cardiovascular and Thoracic Surgery, University of Oklahoma Health Sciences Center, Oklahoma City, Okla.

Disclosures: Author has nothing to disclose with regard to commercial support.

Received for publication Feb 26, 2017; accepted for publication March 3, 2017; available ahead of print March 28, 2017.

Address for reprints: Harold M. Burkhart, MD, Division of Cardiovascular and Thoracic Surgery, University of Oklahoma Health Sciences Center, PO Box 26901, WP-2230, Oklahoma City, OK 73105 (E-mail: Harold-burkhart@ouhsc.edu).

J Thorac Cardiovasc Surg 2017;153:1528-9

$0022-5223 / \$ 36.00$

Copyright $\subset 2017$ by The American Association for Thoracic Surgery

http://dx.doi.org/10.1016/j.jtcvs.2017.03.012

A decade has passed since appointed representatives from leading cardiothoracic surgery entities attended the Visioning Simulation Conference in Cambridge, Massachusetts, sponsored by the Thoracic Surgery Foundation for Research and Education. Shortly thereafter, 3 seminal articles on simulation in thoracic surgery were published in The Journal of Thoracic and Cardiovascular Surgery. In the first article, Carpenter and colleagues ${ }^{1}$ discussed the importance of simulation and its potential to benefit surgical training and patient care. In addition, they outlined specific shortand long-term simulation goals in adult cardiac, thoracic, and congenital cardiac surgery. Chitwood and colleagues ${ }^{2}$ announced a "mission critical" to improve cardiothoracic surgical education in part, with the use of simulation. The third article, by Hicks and colleagues, ${ }^{3}$ reported on the overwhelming success of the first annual simulation-based residents boot camp. Envisioned by American Board of Thoracic Surgery Chair Richard Feins, MD, and sponsored by the Thoracic Surgery Directors Association, the 2.5 days of boot camp brought together 33 cardiothoracic surgery first-year residents and 26 surgical faculty with the common goal of utilizing an innovative simulation-based curriculum to meaningfully influence the residents' surgical education. The fact that this will be the 10th year for the boot camp is a testament to its success.

There is little doubt that surgical trainees derive benefit from simulation-based education. In fact, the Accreditation Council for Graduate Medical Education requires simulation in thoracic surgery residency education. Several studies have shown positive results from using simulation to train cardiothoracic surgery residents. ${ }^{4-7}$ Recently, Feins and colleagues ${ }^{4}$ reported the results of a cardiac surgery resident curriculum employed in a 3-year grant sponsored by the Agency for Healthcare Research and Quality. In that prospective study, 8 academic centers utilized a 39-session simulation-based curriculum to enhance and facilitate resident surgical education. The results were affirmative in that performance of component tasks and cardiac surgical

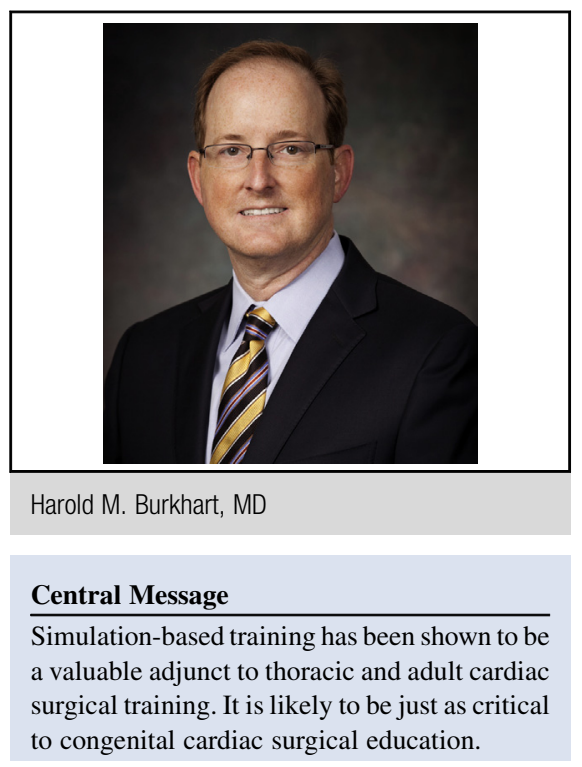

See Article page 1530 .

procedures improved. In addition, residents improved in their ability to manage adverse events such as intraoperative air embolism and aortic dissection.

Yoo and colleagues ${ }^{8}$ present their experience using 3dimensional print models of hearts with congenital heart disease to train surgeons in complex congenital cardiac surgical procedures. Surgical procedures included the arterial switch, Norwood procedure, and repair of double-outlet right ventricle. In all, they had 81 surgeons or trainees take part in hands-on surgical training with the expert surgeons available to supervise. All of the participants who filled out a questionnaire assessment of the course agreed that the use of the 3-dimensional models was helpful with regard to surgical skills and they would consider incorporating similar sessions into their training programs. The weaknesses of the models included the material of the models was different from human tissue and the atrioventricular valves were poorly demonstrated.

Yoo and colleagues ${ }^{8}$ should be commended on their efforts in advancing the educational approach to congenital cardiac surgery. The issues that surround training surgical residents in complex, high-risk surgical operations are numerous. Neonatal cardiac surgery, in particular, has many opportunities for complications due to the complex foreign anatomy, rarity of anomalies, difficulty in visualization from an assistant's viewpoint, and the increased risks 
associated with technical errors and prolonged operations. The requirements for complex neonatal operations in congenital cardiac surgery training are low, with residents feeling less satisfied with their neonatal surgical experience. ${ }^{9}$ The addition of simulation training utilizing models of congenital cardiac anomalies to achieve board certification in congenital cardiac surgery seems a reasonable next step.

\section{References}

1. Carpenter AJ, Yang SC, Uhlig PN, Colson YL. Envisioning simulation in the future of thoracic surgical education. J Thorac Cardiovasc Surg. 2008;135: 477-84.

2. Chitwood WR Jr, Spray TL, Feins RH, Mack MJ. Mission critical: thoracic surgery education reform. J Thorac Cardiovasc Surg. 2008;136:812-3.
3. Hicks GL Jr, Brown JW, Calhoon JH, Merrill WH. You never know unless you try J Thorac Cardiovasc Surg. 2008;136:814-5.

4. Feins RH, Burkhart HM, Conte JV, Coore DN, Fann JI, Hicks GL Jr, et al. Simulation-based training in cardiac surgery. Ann Thorac Surg. 2017;103:312-21.

5. Hicks GL Jr, Gangemi J, Angona RE Jr, Ramphal PS, Feins RH, Fann JI. Cardiopulmonary bypass simulation at the Boot Camp. J Thorac Cardiovasc Surg. 2011; 141:284-92.

6. Burkhart HM, Riley JB, Hendrickson SE, Glenn GF, Lynch JJ, Arnold JJ, et al. The successful application of simulation-based training in thoracic surgery residency. $J$ Thorac Cardiovasc Surg. 2010;139:707-12.

7. Fann JI, Calhoon JH, Carpenter AJ, Merrill WH, Brown JW, Poston RS, et al. Simulation in coronary artery anastomosis early in cardiothoracic surgical residency training: the Boot Camp experience. J Thorac Cardiovasc Surg. 2010;139:1275-81.

8. Yoo S, Spray T, Austin EH, Yun T, van Arsdell GS. Hands-on surgical training of congenital heart surgery using 3D print models. J Thorac Cardiovasc Surg. 2017; 153:1530-40.

9. Kogon B, Karamlou T, Baumgartner W, Merrill W, Backer C. Congenital cardiac surgery fellowship training: a status update. J Thorac Cardiovasc Surg. 2016;151 1488-95. 